\title{
Pigment Epithelium
}

National Cancer Institute

\section{Source}

National Cancer Institute. Pigment Epithelium. NCI Thesaurus. Code C13177.

Tissue consisting of one or more layers of epithelial cells and a basement membrane.

The cells contain granules of pigment or melanin, as in the retinal or iris pigment layer. 